\title{
Crab gatherers perceive concrete changes in the life history traits of Ucides cordatus (Linnaeus, 1763), but overestimate their past and current catches
}

\author{
Juliana de Farias Capistrano ${ }^{1}$ and Priscila Fabiana Macedo Lopes ${ }^{1,2, *}$
}

\author{
${ }^{1}$ Federal University of Rio Grande do Norte, Ecology Department, Natal, RN, Brazil \\ ${ }^{2}$ Fisheries and Food Institute, Ecomar/Unisanta, Santos, SP, Brazil \\ * Corresponding author \\ 凹E-mail address: Lopes, PFM (priscila@cb.ufrn.br)
}

Ethnobiology and Conservation 2012, 1: 7 (8 October 2012) ISSN 2238-4782

doi: $10.15451 / \mathrm{ec} 2012-8-1.7-1-21$

\author{
ethnobioconservation.com
}

\begin{abstract}
The mangrove crab Ucides cordatus (Linnaeus, 1763) is an important resource for the livelihood of several poor families living on the Brazilian coast. However, this species is in the Brazilian list of threatened aquatic species, although not much is known about its stock situation. This study aimed to assess the situation of $U$. cordatus fisheries, comparing biological data, obtained through crab landing sampling, to information provided by crab gatherers. For that, data sampled along 12 years in a coastal municipality on the Brazilian northeast (Canguaretama, Rio Grande do Norte) were compared to interviews with $30 \mathrm{crab}$ gatherers from the same municipality regarding changes in fishing and in the crab life history traits during the same 12 years. Long temporal analyses and intense data collection like these are relatively rare in developing countries. Therefore, comparing their efficiency to the data obtained through interviews could confirm the efficacy of this last method in obtaining quality data in a quick and inexpensive way. The crab landing sampling indicated an increase in catch and a decline in the Catch per Unit of Effort (CPUE), while the biological data showed an increase in male crab proportion in the sex ratio and a decrease in the carapace length of both sexes. Crab gatherers were able to provide accurate information on crab life history traits, but overestimated their catch. This suggests that information provided by gatherers and probably by resource users in general may have some limitations, although it could provide cheap and reliable information, depending on the topic investigated.
\end{abstract}

Keywords: Crab fishery - Temporal fishery series - Artisanal fisheries Ethnobiology - Fishermen's knowledge and conservation 


\section{Introduction}

On a regional and local scale, stock assessments are uncommon or not performed for many invertebrate fisheries (Andrew et al. 2002). This is worse for species with low commercial values, which are usually subjected to fewer scientific studies and often neglected in the statistics showing the fishing production of a country (Ronnback 1999). As a consequence, there is also lack of adequate knowledge on the species biology, population status, and on how the stock responds to the exploitation level (Anderson et al. 2008). Based on such limited knowledge, establishing limits and goals for sustainable exploitation of invertebrates may be difficult to achieve (Perry et al. 1999). This explains the lack of specific management policies to some particular groups, such as mangrove crabs (Goes et al. 2010). However, there is evidence suggesting that an increasing percentage of invertebrate fisheries may be fully exploited, over-exploited, collapsed or closed (Anderson et al. 2011).

In the marine ecosystem, the impact of human exploitation is not equally distributed over different substrates or over different groups (De Boer et al. 2002). For example, benthonic sedentary species tend to suffer different exploitation intensity during the low tide. This is the specific case of the mangrove fauna, which can suffer greater exploitation due to its exposure during low water neap tides, which makes this fauna easily available for exploitation while the other substrates are still flooded (De Boer et al. 2002). The influence of the phases of the moon and of the tide variation on activities of crustacean and mollusk gatherers were also reported by Nishida et al. (2005).

To properly manage the exploitation of invertebrates or of any other group of interest to fisheries, ideally it would be necessary to have some information on stock changes, regardless if such changes are due to natural causes or a consequence of human intervention (Anderson et al. 2011). However, obtaining this data requires intense data collection and long temporal series, which normally imply in high costs and in the existence of qualified personnel, both limiting factors in developing countries (Moura et al. 2009). For example, there is evidence that in Brazil a decrease in investments in research per capita can jeopardize scientific quality, by restricting the possibility of producing high-impact science (Helene and Ribeiro 2011), or even the monitoring of its natural resources.

An alternative to partially provide low cost data about resources, such as fish and crustaceans, is through interviews with resource users, such as fishermen, peasants and resource extractors in general (White et al. 2005). Clearly, interviews have some constraints, for example, the honesty of the interviewees (Lunn and Dearden 2006), especially in situations where informers have reasons to under- or over-report their activities (Jones et al. 2008). Even when they are not dishonest, people may not provide information that corresponds to their real perception and level of extraction. For example, in a study done in Madagascar, even though the fishermen were asked individually about their fishing catch, their answers tended towards the population catch average rather than their personal actual catches (Jones et al. 2008).

In Brazil, artisanal fishery represents up to $60 \%$ of the total catch (Paiva 1997). However, this estimative rarely considers the catch of invertebrates of low commercial value, such as some clams and mangrove crabs (Erman 1996). The extraction of these animals is usually associated with low-income human groups, to whom they represent an important source of food and financial complement, 
especially in the northeastern region of the country (Fiscarelli and Pinheiro 2002). In some rare occasions, there is a systematic monitoring of the catches of these animals done by state and/or federal institutions responsible for providing the fishing statistics (Vasconcellos et al. 1999). However, even when there is such statistics, there is also lack of adequate interpretation of the data.

On the Brazilian northeast, the catch of the mangrove crab Ucides cordatus (Linnaeus, 1763) is an activity hardly ever taken into account by resource managers and policy makers in general, despite its relevance for local food and financial security (Barboza et al. 2008) and despite this species being in the National List of Species of Aquatic Invertebrates and Fishes Endangered, Overexploited or Threatened by Exploitation (MMA 2004). Only a few studies have focused on the exploitation of $U$. cordatus, while some have investigated the behavior and the knowledge of crab gatherers (Alves and Nishida 2002; Alves et al. 2005, Nordi et al. 2009; Fiscarelli and Pinheiro, 2002; Firmo et al., 2011). Nevertheless, in an important crab extraction site in Rio Grande do Norte state (Canguaretama municipality), systematic samplings of crab landings have been done since 2000 by the Brazilian Federal Environmental Agency (IBAMA), offering a unique opportunity to have more detailed studies about the $U$. cordatus stock.

It is in this context that the present study sought to highlight possible variations in the stock (catch, effort, sexual ratio and crab size) throughout 12 years. Moreover, it also aimed to analyze the perception and accuracy of the information given by the community of crab gatherers in relation to the same variables assessed in the stock, as a way of seeking for an alternative tool to collect data related to species stock in the absence of systematic monitoring of the extraction (Thomas 2007). It was expected a decrease in the catch due to increasing fishing pressure, which, in its turn, was expected to be also realized by the crab gatherers. Likewise, it was expected a decrease or stability in the Catch per Unit of Effort (CPUE), indicating an increase in the fishing effort and a decrease or the maintenance of the total catch, which should also have been noticed by the crab gatherers. It was also expected an increase in the amount of females and on the number of small individuals, as both supposedly do not suffer commercial pressure, as their catch is forbidden by law.

Temporal series like this one are relatively rare in developing countries. Thus, comparing the data obtained through interviews to regular landings could confirm the efficacy of the first method in obtaining quality data in a quick and inexpensive way, two essential characteristics to obtain information about the fishery data on several parts of the developing world (Jones et al. 2008; White et al. 2005).

\section{Material and Methods}

\section{Study site}

Canguaretama is a small town [31,216 inhabitants; total area $=245 \mathrm{Km}^{2}$ (IBGE, 2011)] located on the southern shore of Rio Grande do Norte State, on the northeastern Brazilian coast. Its main economic activities are: small-scale agriculture, shrimp farming, crab and shell extraction and fishing. The Curimataú river crosses the town, forming a large mangrove area on its estuary, of approximately 3,300ha (Souza 2004) (Figure 1). 
The climate is classified as tropical rainy with an average annual temperature of $25.6^{\circ} \mathrm{C}$. The rainy season is from April to July and the driest months are from September to January.

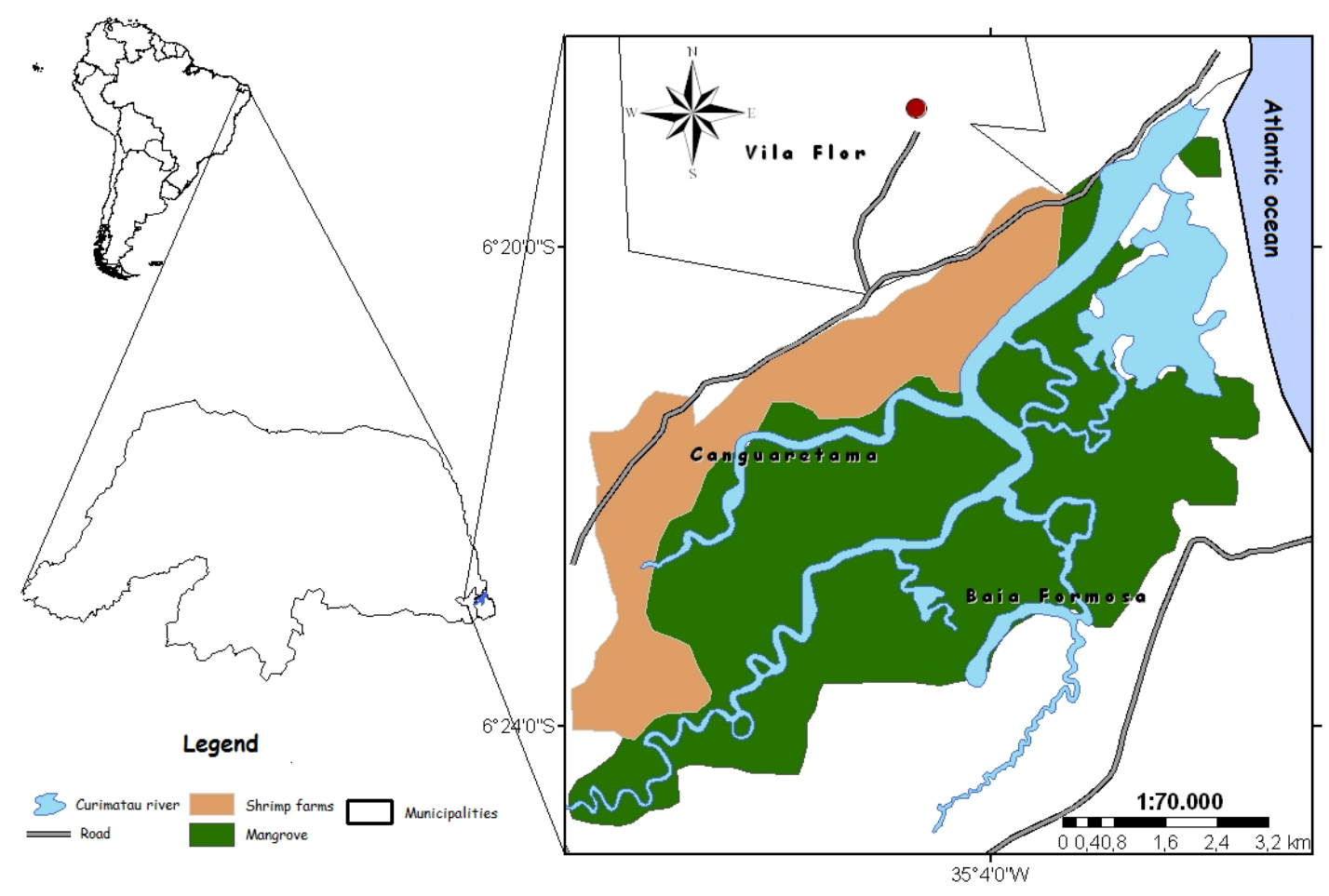

Figure 1. The study area highlighting the estuary of the Curimataú river (Canguaretama, Rio Grande do Norte, Brazil), where the crab gathering activity takes place.

\section{Studied groups}

\subsection{Ucides cordatus}

Ucides cordatus (Linnaeus, 1763) (Brachyura, Ocypodoidea, Ucididae) is a semi-terrestrial species, restricted to mangrove areas, inhabiting galleries dug in areas of muddy to sandy-muddy substrate, near the sea, between the mean levels of high and low tide (IBAMA 2011). This species occurs from Florida (southern USA) to Santa Catarina (southern Brazil) (Melo 1996). The importance of this crab goes beyond its economic relevance for some Brazilian communities, it also plays an important ecological role, being considered a keystone species (Schories et al. 2003; Diele et al. 2005) and an ecosystem engineer, for constantly modifying its habitat (Kristensen 2008).

However, this species is currently on the Brazilian List of Aquatic Invertebrates and Fish Species overexploited or threatened by overexploitation (MMA 2004). Aside from overfishing and selective catch, which cause changes on population and individuals size, the stability of $U$. cordatus populations has been threatened by the 
widespread destruction of mangroves (Amaral and Jablonski 2005) for developments and shrimp farms.

\subsection{Crab gatherers}

Among the fishermen, crab gatherers are the group with the lowest average income (Nordi 1992). In general, crab gatherers tend to establish themselves on the periphery of urban coastal zones, usually the poorest ones.

Many of the gatherers are male, due to the risk of accidents associated with this activity: women are normally responsible for cleaning and commercializing the animals (Fiscarelli and Pinheiro 2002). However, those activities performed by women are seen by others in their communities as an extension of women's housework tasks and are undervalued when compared to the men's work of gathering crabs from the mangrove, even though both kinds of activities contribute to the wellbeing of the household (Magalhães et al. 2007).

In Canguaretama, 30 gatherers were interviewed, of which only one was a woman. These gatherers are around 47 years old and most of them were born in Canguaretama (60\%). On average, the gatherers have been working with this activity for around 23 years and almost $74 \%$ of them depend on $U$. cordatus specifically as their main source of income.

\section{Data source}

The crab landing data used here to evaluate the stock variation and changes in some of the life history traits of $U$. cordatus were collected in the study site and provided by The Brazilian Institute of Environment and Renewable Natural Resources (IBAMA). The landings have been sampled since 2000, so the data used here encompasses the period between 2000 and 2011. The biological data on sex ratio and carapace width was sampled by IBAMA from 1995 to 2004.

\subsection{Crab Landing}

The data on crab landing (total catch, number of gatherers, kind of vessel if any, kind of gear and the arrival and departure dates) were daily collected, from 2000 to 2011, in the main fishing port of Canguaretama, by the IBAMA staff. The employee in charge took note of the number of crabs collected by each gatherer, a number that was later converted to weight in kilograms (7 crabs weights approximately $1 \mathrm{Kg}$ ). Crabs are extracted in other rural communities of Canguaretama as well, which were not regularly sampled by IBAMA. In these cases, once a month the employee visited these communities and checked how many gatherers worked that month, by asking the gatherers themselves. Then, by a direct relation with the data sampled on the main fishing port of Canguaretama, considering the number of gatherers and the total catch of crabs, the value was extrapolated to the monthly catch of the whole municipality. For example, if in the main port 10 vessels had caught $1,000 \mathrm{~kg}$ of crab, and they knew that there were 20 vessels working in the other communities, by a linear extrapolation it was assumed that the other communities had caught $2,000 \mathrm{~kg}$ of crab. 


\subsection{Population biology}

The data on the biology of the studied population were collected monthly from 1995 to 2004, by sampling crabs randomly during the neap tide period. For these samples, IBAMA hired a crab gatherer and authorized him to take all the crabs he could find in the mangrove, without any restrictions of animal sex or size. These individuals were then properly measured in the laboratory. Here only data on sex ratio and carapace width was considered.

There was no data collection during some months, such as, in January and April 2009 and in January 2010, due to the vacation period of the only employee in charge of sampling this data.

\subsection{Environmental Perception}

The environmental perception data collection of the crab gatherers was done through in loco interviews performed in the first semester of 2012. The questionnaire had 19 direct questions (Supplementary Material), including questions about possible environmental changes in the mangrove, the perception and evaluation of the gatherers towards the supervision and rules related to this activity, the year of the highest catch of $U$. cordatus, the good and bad months to catch crabs and the perception of the gatherers about possible changes on landing variables (total catch, number of gatherers, kind of vessel and the time spent on the activity), possible changes in the size and sex ratio of crabs in the last 10 years (from 2001 to 2011). The crab gatherers were selected by two criteria: (1) he had to be living in the municipality for at least 10 years, and (2) he had to be catching crabs for at least 10 years. These criteria were established to match the IBAMA data collection period, and resulted in the interview of 30 crab gatherers.

\section{Data analyses}

\subsection{Crab landing}

A Generalized Linear Model (GLM) analysis was used with the goal of understanding which factors affect the payoff of a crab gathering event (catch measured in $\mathrm{kg}$ ), having as independent variables two numerical variables (number of gatherers working together in one gathering event; and number of days catching crabs during one event) and three categorical variables (type of vessel: canoe or disembarked fishing; month: from January to December; and year of the event: from 2000 to 2011), considering all the landings sampled over the 12 years $(n=10,301)$. For this analysis, it was used a Poisson distribution with a logit link function.

A Kruskal-Wallis test was used to compare the variations of the total catch throughout the sampling period (months and years), given the non-homogeneity of the variances. Besides, the months were separated in two groups of six, gathered according to the life history traits of $U$. cordatus, one group was the moult and premoult phase (May, June, July, August, September and October) and the other representing the post-moult phase (January, February, March, April, November and December), to check how the catch varied between these two categories. A Levene test was done to check the homoscedasticity of the variances of the two groups (Fox, 
2005). After the result of this analysis a Test $T$ of Student for unequal variances was run.

In this study, the catch was measured as kilograms of crab converted from the total number of individual crabs and effort was estimated by number of gatherers and time fishing. However, time fishing was measured in number of days, as the number of hours in which the crab gatherers were working was not assessed. Thus, the CPUE was defined as total $\mathrm{kg}^{*}$ number of gatherers ${ }^{-1 *}$ catching days ${ }^{-1}$. CPUE is commonly used to infer trends on stock size (Siren et al. 2004), observing how the total catch relates to the effort.

The average CPUE was compared over the years by a one-way ANOVA.

\subsection{Population biology}

For the sex ratio analysis, the proportion of male and female crab over the years was estimated and then compared through a chi-square analysis to estimate if there was a significant difference on the proportions of each sex over the years.

A Kruskal-Wallis test was used to check if the average width of the carapace of individuals varied throughout the years, for both males and females, given the nonhomogeneity of the sampled data.

\subsection{Environmental perception}

A Test $t$ of Student for unequal variances was used to compare the data obtained through crab landing sampling to the information given by the interviewees, on total catch and effort (number of fishers per event, number of days collecting crabs). The answers given by the gatherers about 10 years ago were compared to the data of total catch per day sampled by IBAMA in 2002, while the information given about current catch per day (relatively to the time of the interview: first semester of 2012) were compared to the most recent (2011) data provided by IBAMA.

The other questions in the questionnaire were only qualitatively assessed. For example, the crab gatherers' perception on changes in sex ratio and crab size was qualitatively compared to changes observed in the biological sampling, regarding the same issues. However, since the biological sampling ended in 2004, it was only possible to infer trends that are not directly compared to the current perception (first semester of 2012) of a gatherer.

All the statistical analyses were done using the free software $R$ ( $R$ Development Core Team 2012).

\section{Results}

\section{Crab landing}

\subsection{Catch and CPUE}

The crab gatherers of this study caught a total of $629,915.10 \mathrm{Kg}$ of $U$. cordatus between 2000 and 2011. This last year of sampling was the one with the highest total 
catch $(81,974 \mathrm{Kg})$, equivalent to $13 \%$ of the total. The total catch varied annually from $7,193 \mathrm{Kg}$ to $81,974 \mathrm{Kg}$, with an average of $52,493 \mathrm{Kg}( \pm 25,354 \mathrm{Kg})$ per year (Figure 2). When the total catch was analyzed monthly, it was noticed that the lowest catches happened between June and October, when it was observed an average catch of $3,844.2 \mathrm{Kg} \pm 1,930.0 \mathrm{Kg}$ (Figure 3). The average catch for the remaining months of the year (Nov-May) was $4,949.3 \mathrm{Kg} \pm 2,699.4 \mathrm{Kg}$. The catches were significantly different among years $(\mathrm{KW}=3,236.98 ;$ d.f. $=11 ; \mathrm{P}<0.0001)$ and months $(\mathrm{KW}=$ $6,265.01 ;$ d.f. $=10 ; \mathrm{P}<0.0001)$.

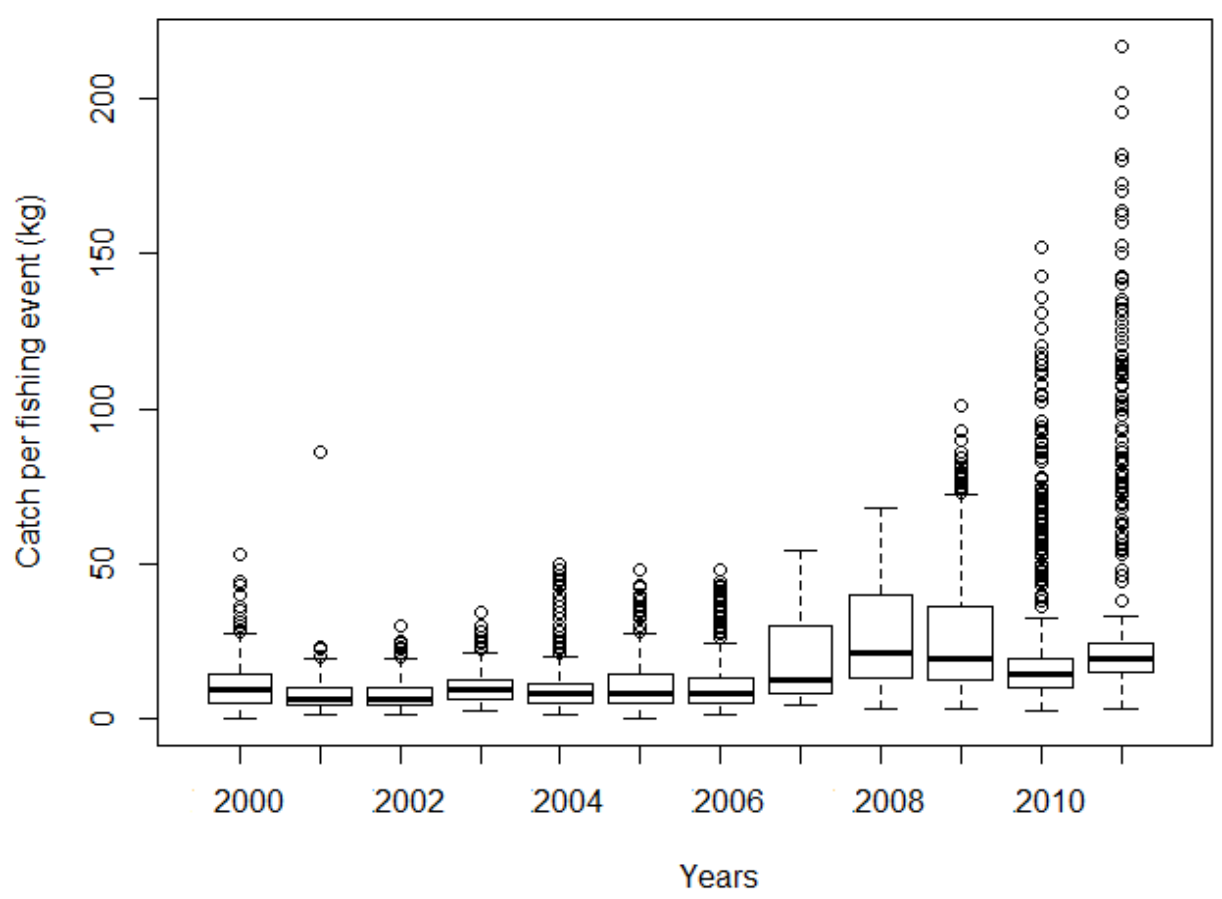

Figure 2. Comparison of the catch $(\mathrm{kg})$ of Ucides cordatus (Linnaeus, 1763) per fishing event along the years. The landings were sampled in Canguaretama municipality, Rio Grande do Norte, Brazil. The box plot shows the median (darker line), minimum and maximum values (vertical lines) and quartiles (outer lines of the box plot, representing $25 \%$ and $75 \%$ ). Circles are outliers.

The Test $t$ of Student for unequal variances (Levene test: $F=2.8051$; d.f.= 105; $P>0.001)$ used to compare the means of crab landing catches between the months that corresponded to the pre-moult/moult and post-moult phase showed a significant difference $(t=6.331 ; d f=10,274.92 ; P>0.001)$ : catches were higher in the pre-moult/moult phase. 


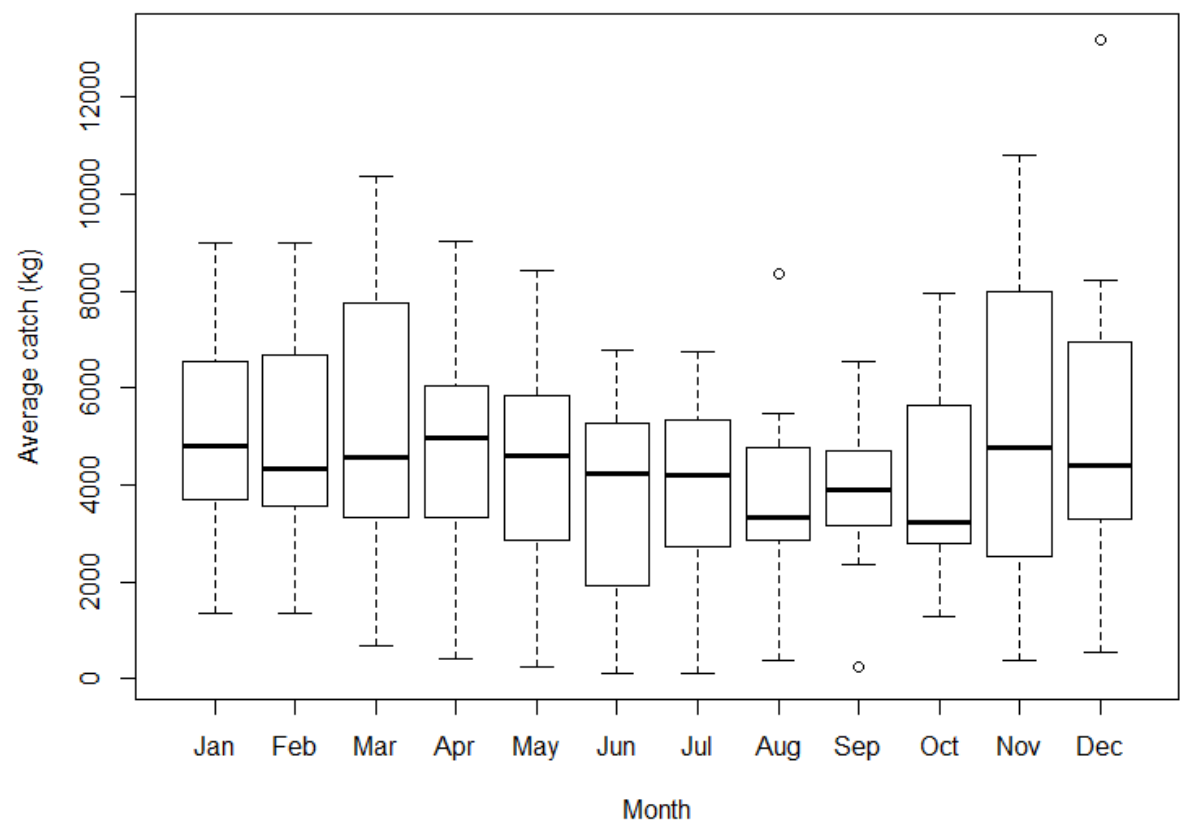

Figure 3. Comparison of the average catch $(\mathrm{kg})$ of Ucides cordatus (Linnaeus, 1763) per fishing event along the months. The landings were sampled in Canguaretama municipality, Rio Grande do Norte, Brazil. The box plot shows the median (darker line), minimum and maximum values (vertical lines) and quartiles (outer lines of the box plot, representing $25 \%$ and $75 \%$ ). Circles are outliers.

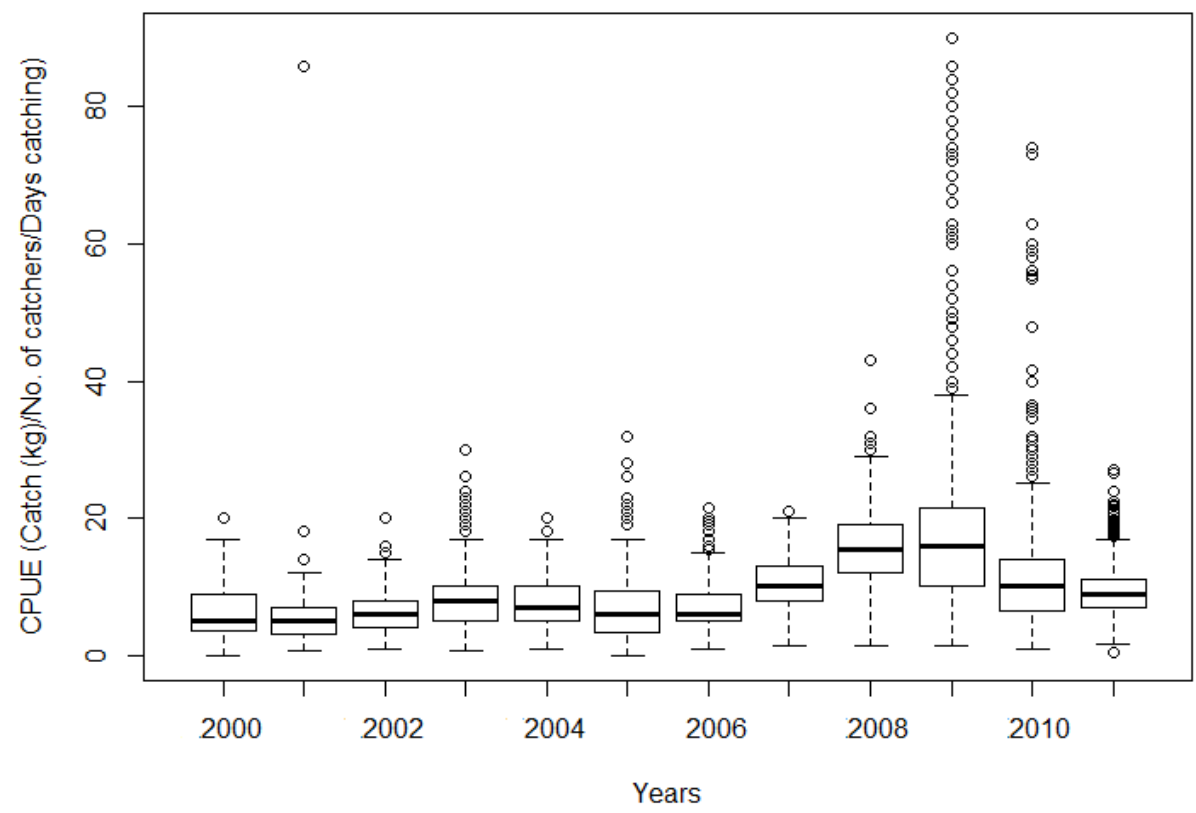

Figure 4. Catch per Unit of Effort (CPUE) per year in Canguaretama, RN, Brazil. The CPUE was defined as total $\mathrm{kg}$ of crab caught per trip number of gatherers ${ }^{-1}{ }^{*}$ catching days ${ }^{-1}$. The box plot shows the median (darker line), minimum and maximum values (vertical lines) and quartiles (outer lines of the box plot, representing $25 \%$ and $75 \%$ ). Circles are outliers.

The resulting GLM indicated that the two temporal variables (year and month) and the three effort variables (kind of vessel, number of gatherers and number of days fishing $)$ affected significantly the total catch $(\mathrm{AIC}=82481 ; \mathrm{P}>0.001)$. However, the month of October was the only non-significant one $(Z=0.597 ; P>0.001)$ (Supplementary Material). 


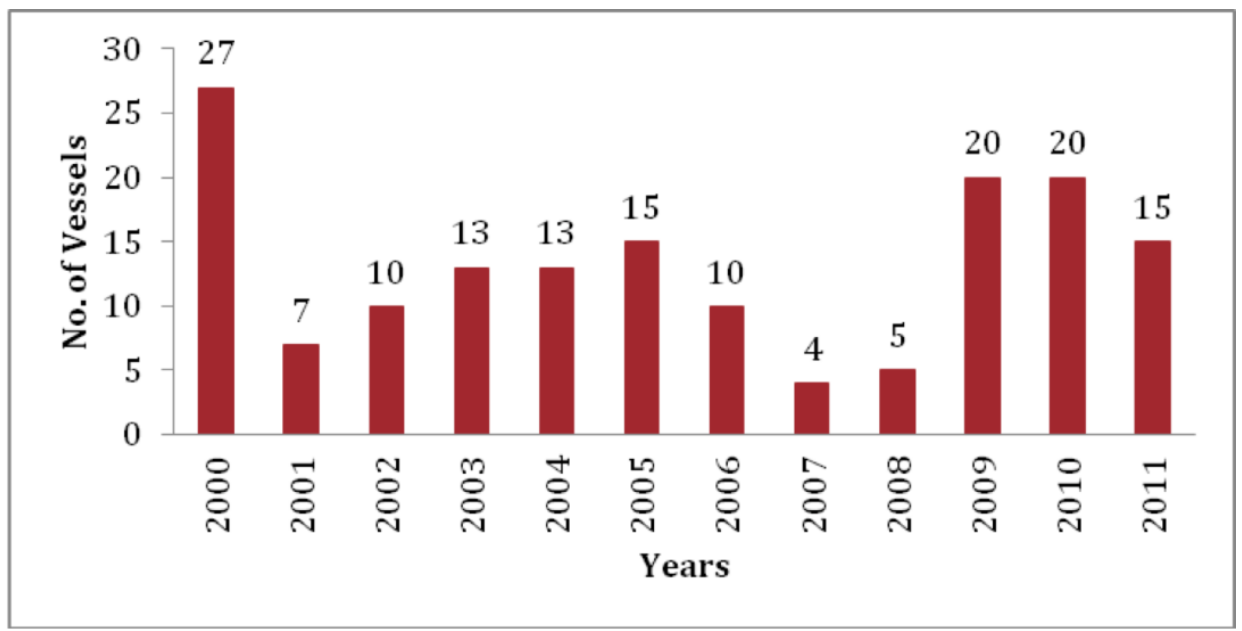

Figure 5. Total number of vessels operating per year on the catch of Ucides cordatus (Linnaeus, 1763) in Canguaretama, Rio Grande do Norte, Brazil.

The CPUE analysis presented an increase between 2000 and 2008, but decreased after that, showing a significant difference among months $(F=342.3$; d.f. $=$ 11; P>0.001) (Figure 4).

The amount of vessels also varied throughout these 12 years, reaching the maximum value of 27 vessels in 2000 and the minimum of four in 2007 (Figure 5). However, the average number of crab gatherers per fishing vessel varied slightly, never exceeding the average of two.

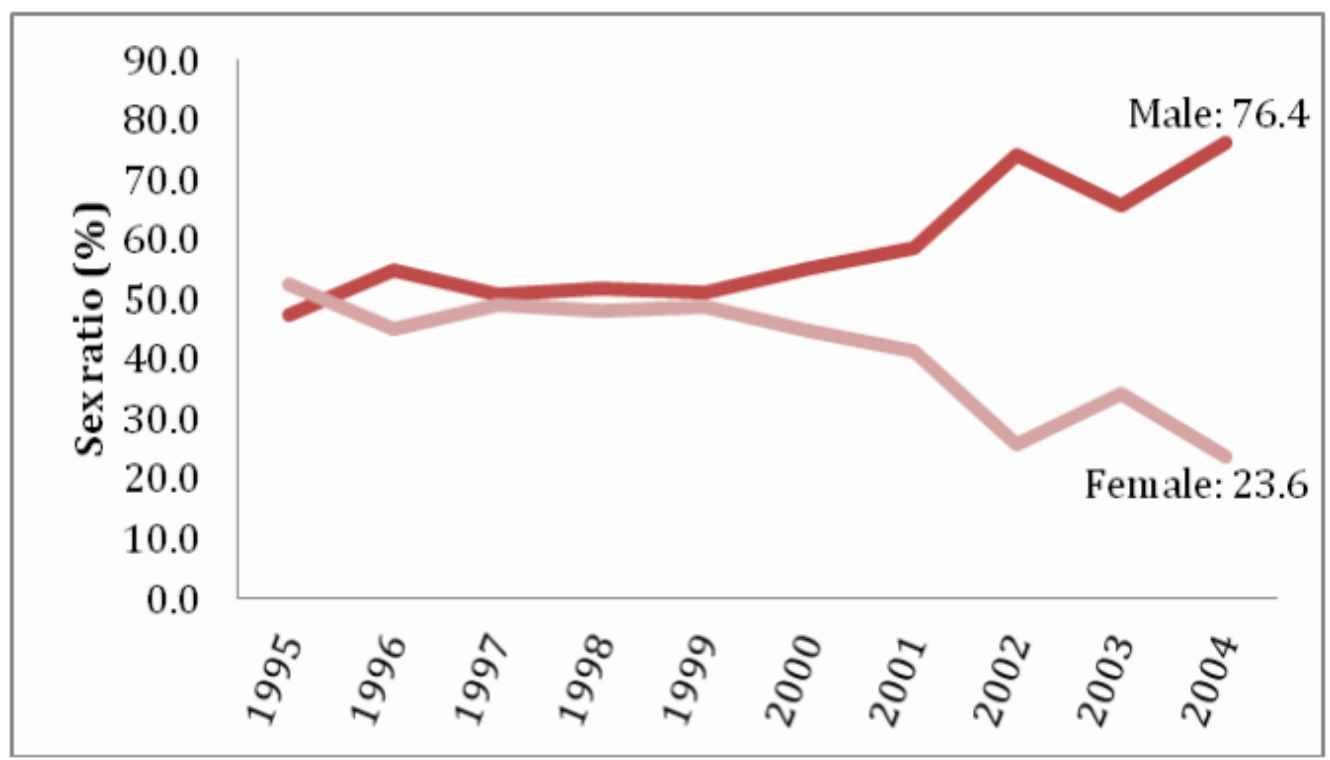

Figure 6. Proportion of male and female crabs per year, from 1995 to 2004, sampled in Canguaretama municipality, Rio Grande do Norte, Brazil. 


\section{Population biology}

\subsection{Sex ratio and size of Ucides cordatus}

A total of 13,864 crabs collected between 1995 and 2004 were used to evaluate the sex ratio and the carapace width of the sampled population. The sex ratio had variations along the years. From 1995 to 1999 it was observed a small difference between the sexes, reaching the maximum of $55 \%$ of male crabs versus $45 \%$ of female. However, from 1999 on that difference increased, reaching the highest variation in 2004 (the last year with available information), when $76 \%$ of the crabs sampled were males (Figure 6). The differences observed on the sex ratio along the years was significantly different $\left(X^{2}=546.61\right.$; d.f. $\left.=9 ; P>0.001\right)$.

Likewise, the width of the carapace also varied in a significant way along the years, for both female and male crabs (respectively, $\mathrm{K}-\mathrm{W}=2,189.49$; d.f. $=9 ; \mathrm{P}<$ $0,001) / K-W=2,229.20$; d.f. $=9 ; P<0.001)$. The values of maximum and minimum carapace width for male crabs were, respectively, $65.3 \mathrm{~mm}$ and $47.3 \mathrm{~mm}$, and for female crabs were $67.4 \mathrm{~mm}$ and $45.1 \mathrm{~mm}$ (Figure 7). The maximum values happened in 1995 and the minimum ones were observed in 2000.

\section{Contrasting the crab gatherers' environmental perception and landing data}

\subsection{The mangrove and the stock of Ucides cordatus}

When asked about the changes that happened in the mangrove in the last decade, $44 \%$ of the gatherers indicated that since they began catching crabs in the area they perceived an increase in the number of shrimp farms, followed by deforestation (28\%). The remaining interviewees did not notice any change $(13 \%)$ or reported an increase in mangrove pollution (6\%), while $9 \%$ claimed that the mangrove was in a process of recovery. Yet, $71 \%$ of the gatherers said they observed a decline on the amount of $U$. cordatus, while $19 \%$ reported an increase and the remaining affirmed that there was no alteration on the stock of the species.

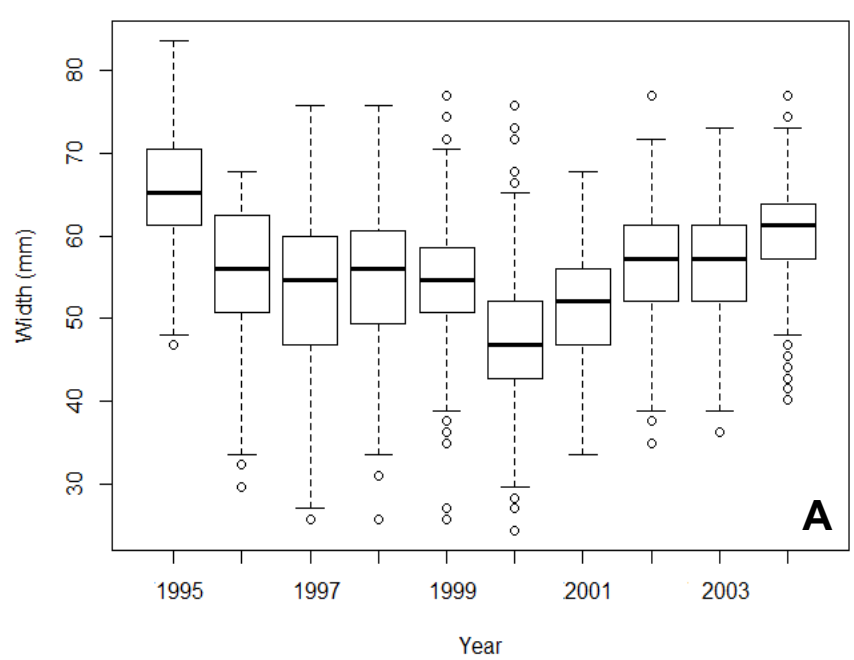

Figure 7. Carapace width in millimeters of male $(A)$ and female $(B)$ crabs (Ucides cordatus Linnaeus, 1763), collected in Canguaretama municipality (Rio Grande do Norte, Brazil), from 1995 to 2004.

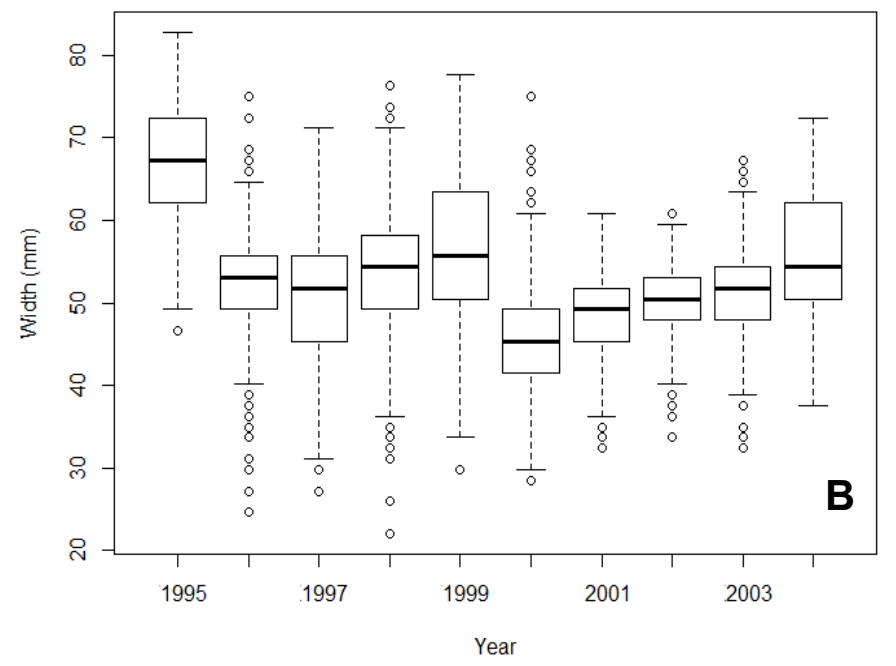


When they were questioned about the reasons that could have led to a possible decrease on the stock of $U$. cordatus, the mentioned factors were: the presence of shrimp farms (36\%), an increase in the number of gatherers $(25 \%)$, an increase in the amount of gatherers who are not from Canguaretama municipality (14\%), deforestation (11\%), and the use of a relatively new method ("redinha") $(11 \%)$, which is considered more efficient and, as such, more predatory by some of the gatherers. This method consists of a trap prepared from polypropylene bags shredded and tied up at the tip and placed at the entrance of crab galleries (Alves and Nishida 2003).

Although $71 \%$ of the interviewees reported a decline in the species stock in the study area, $40 \%$ said that the fishing event in which they had the highest catch since they started working with this activity was in 2011. According to them, in this event they caught an average of 139 crabs. Indeed, the crab landing data showed 2011 as the year with the highest average catch. However, the average catch related to this year $(218$ crabs/day \pm 238.6$)$ showed a higher value than what was reported by the gatherers.

On a monthly scale, according to the crab gatherers, the months with the lowest catches were, respectively, June, July and May, when the crabs are "fatter" and it is harder to catch them. The months mentioned as responsible for the highest catches were January, February, March and December, respectively, when the crab is "thinner". This period that goes from January to March matches the species reproductive phase, in which it is legally forbidden to catch crabs for about six consecutives days in each of these three months. The number of days defining the monthly closed season is set according to the new and full moon phase (IBAMA 2001).

According to the monthly average catch observed in the landings, after May the average catch per month starts dropping reaching its lowest values in June and July. Similarly, the period of highest catch reported by the respondents is in agreement with the average monthly catch over this 12 years period (December and March), in which December showed the highest average per month $(5,234.8 \mathrm{Kg} \pm$ $3,410.7 \mathrm{Kg}$ ).

\subsection{Temporal analyses}

Most gatherers (67\%) affirmed that since 2002 male crabs were more abundant than females and $80 \%$ reported a higher amount of larger individuals in 2002 than nowadays. The biological data analyses showed that in 2002 the sex ratios were highly different ( $74 \%$ of males) (Figure 6 ), although there is no current data to be compared with the information provided by the gatherers (Table 1).

Still, in 2002, the most common kind of technique to catch crabs, according to the interviewees, was the manual ones (no tool) (83\%), which is in agreement with the data collected in the landings. In $2011,74 \%$ of the gatherers affirmed to catch crabs using the "redinha", $19 \%$ reported the use of no tool (manual) and $6 \%$ said to use a gear made of an oil can. The landing data, on the other hand, showed that $100 \%$ of those interviewed reported to IBAMA the use of manual techniques.

In 2002 the canoes were the transportation mode used by most of the gatherers $(87 \%)$ to get around the mangrove, while the remaining used to do the disembarked fishing (on foot), whereas in 2011 the canoe was indicated as the 
method used by $90 \%$ of the gatherers. According to the landing data, in both 2002 and $2011,100 \%$ of those interviewed used the canoe to get around the mangrove.

On average, in 2002, according to the interviewees, there were four crab gatherers per vessel, who stayed in the mangrove for about 23 hours and use to catch around 116 crabs per day. The landing data for the same period showed that the time spent by the gatherers in the mangrove was around 24 hours, the number of gatherers per vessel was two (maximum) and the total catch per day was an average of 54 crabs. In 2011, though, the crabbers reported an amount of three gatherers (maximum) per canoe, who spent around 31 hours, catching approximately 103 crabs per day. The landing data for 2011 indicated an average of 48 hours spent on catching crabs and three gatherers per canoe, who caught about 98 crabs per day (Table 2).

The total catch per day mentioned by the interviewees was significantly different (in 2002: $\mathrm{T}=-5.7058$; d.f. $=29 ; \mathrm{P}>0,001 /$ in 2011: $\mathrm{T}=8.7381$; d.f. $=90 ; \mathrm{P}$ $>0,001)$ from the values collected in the landings.

Table 1. Comparison of the most mentioned answers given by the crab gatherers during the interviews in relation to the sex ratio, crab size, gear/technique used to catch crab and vessel type used to go fishing (if any), for 2002 and 2011, and the pattern of the data observed in the actual crab landings and biological data. Both the landings and the interviews were sampled in Canguaretama municipality, Rio Grande do Norte State, Brazil. Numbers in parentheses represent the percentage of crab gatherers who agreed on the respective answer.

\begin{tabular}{cccc}
\hline Attribute & $\begin{array}{c}\text { Interview about } \\
\text { situation in } 2002\end{array}$ & 2011 & Trend \\
\hline Sex & Male (67\%) & Female (50\%) & Small (50\%) \\
Size & Big (80\%) & Redinha $(74 \%)^{\text {a }}$ & Manual \\
Gear & Manual (83\%) & Canoe $(90 \%)$ & Canoe \\
\hline
\end{tabular}

\footnotetext{
${ }^{a}$ Redinha corresponds to a trap prepared from polypropylene bags shredded and tied up at the tip and
} placed at the entrance of crab galleries (Alves and Nishida 2003). See the text for further information. 
Table 2. Comparison of the most mentioned answers given by the crab gatherers during the interviews and the data observed in the actual crab landings, for 2002 and 2011. Comparison of the most mentioned answers given by the crab gatherers during the interviews in relation to the catch per day, number of gatherers working in the same crew, time spent catching in one catching event and the resulting CPUE, for 2002 and 2011, and the data observed in the actual crab landings. Both the landings and the interviews were sampled in Canguaretama municipality, Rio Grande do Norte State, Brazil. Values represent averages, unless stated otherwise.

\begin{tabular}{ccccc}
\hline & $\begin{array}{c}\text { Interviews about the } \\
\text { situation 10 years } \\
\text { ago (2002) }\end{array}$ & $\begin{array}{c}\text { Crab } \\
\text { landing } \\
\text { data (2002) }\end{array}$ & $\begin{array}{c}\text { Interviews about } \\
\text { the present } \\
\text { situation (2012) }\end{array}$ & $\begin{array}{c}\text { Crab landing } \\
\text { data (2011) }\end{array}$ \\
\hline Catch (Crabs/day) & 115 & 54 & 103 & 98 \\
Number of gatherers & 4 & Max. 2 & 3 & Max. 3 \\
Time catching & 23 & 24 & 31 & 48 \\
$\begin{array}{c}\text { (hours) } \\
\text { CPUE (catch/Number } \\
\text { of gatherers/hours) }\end{array}$ & 1.25 & 1.12 & 1.1 & 0.68 \\
\hline
\end{tabular}

\subsection{Monitoring and Regulation}

The exploitation of $U$. cordatus is regulated by the environmental agency (IBAMA), which can set specific state rules. These rules define the size (carapace width), sex and period of the year in which the catch of this species is allowed or forbidden. All the crab gatherers said to agree with the prohibition of the catch during the closed period and the commercialization of females and small crabs $(<6 \mathrm{~cm}$ carapace width), as they claim to understand the importance of these two groups to the maintenance of the population. However, $37 \%$ reported to disagree with the prohibition of catching crabs throughout the reproductive phase (from January to March), for two main reasons. Currently, there are two legal stops of six days each on each of these months, totaling six stops a year. However, some of the informants $(23 \%)$ affirmed that only one stop a month would be enough and would cause fewer losses on their monthly income, especially because according to them the crab is reproducing only in one phase of the moon (full moon). The second reason refers to the non existence of a financial support to the gatherers during this reproductive period.

\section{Discussion}

\section{Catch and CPUE}

Estimates about $U$. cordatus stocks are uncommon in Brazil, although some authors indicate a possible depletion of this resource along the Brazilian coast caused by overexploitation (Botelho et al. 2000; Jankowski et al. 2006). The catch of this species consists in one of the oldest extraction activities in mangroves (Pinheiro 
and Fiscarelli 2001). In some Brazilian coastal towns, the exploitation of this species is one of the main fishing products, representing a great deal of the local fishing production (IBAMA 2001).

Considering the historic series of the Brazilian production of $U$. cordatus, the federal environmental agency, in its National Management Plan for Sustainable Use, indicated that there was a reduction in the total catch of this species of approximately 43\% between 1995 and 2007 (IBAMA 2001). Nevertheless, the total catch in Canguaretama (RN) between 2000 and 2011 did not follow this national trend, actually showing an increase in the catch. The monthly variations observed in this study are common to this species, as it is shown on surveys in many different parts of Brazil (IBAMA 2001). This can happen due to natural fluctuations on the annual or seasonal recruiting, although some important local stock reducing factors are also suggested as possible causes for such variations, such as overfishing (Branco, 1993), the mangrove destruction (Diele et al. 2005), and the mortality caused by the Lethargic Crab Disease (LCD) (Boeger et al. 2005; Schmidt et al. 2005). Nevertheless, assuming an increase in the catch for this study based on the average catch can be misleading, as it is shown by the median analysis. When the median is considered, which represents the central values of the distribution, it is possible to observe that, for most landings, the catch did not vary much along the years. What stands out between 2009 and 2011 are the positive outliers, which influences the data mean, overestimating it. The gatherers, however, perceived a reduction in stock throughout the last 10 years, even though the values reported by them were different from those actually observed in the landings, for both the past and nowadays.

It was observed that the CPUE varied significantly along the years, first increasing until 2009 and reducing afterwards. The interviewees also observed this decrease, as it was shown with the CPUE calculated based on their information on total catch, time spent catching and crew size. The increase first observed in this parameter could be explained by a raise in the catch, by keeping the effort constant or by reducing it. The decline after 2009 could have happened due to an increase on the catch effort, and not necessarily in response to an expansion on the stock of $U$. cordatus.

The fluctuation in the CPUE values could be better explained if there were real information about the kind of gear used by the gatherers. During the interviews $74 \%$ of the gatherers affirmed they use the "redinha", while in the landing data was registered that $100 \%$ of those interviewed used manual techniques. Probably, that happened due to the illegality of this gear, considered predatory even by the same gatherers interviewed. The use of this technique has been considered damaging to the environment because it maximizes the catching pressure (Jankowsky et al. 2006), does not select the size or sex of the crab, pollutes the mangrove area, when the remaining material is disposed anywhere, and causes deforestation, as mangrove roots are used to fix this trap (Botelho et al. 2000; Nascimento et al. 2011). In another state of Brazil (Pernambuco), for example, it is estimated that one gatherer uses, on average, 130 redinhas/day and spends 18 days per month catching crabs, which results on 28,080 redinhas/year/ gatherers (Botelho et al. 2000). However, other studies have shown that experienced gatherers are able to identify the size and the sex of the crab based on its trail close to the crab's gallery entrance (Alves et al. 2005). If that is so, it is unreasonable to expect that experienced gatherers, such as the ones considered in this study, would necessary deplete the stock. Gatherers, regardless of the method, will be able to choose the animals they want to catch, which are the big and most valuable ones (usually 
males). The redinha can, on the other hand, maximize their success. The crab gatherers from Paraíba, another Brazilian northeastern state, gave reasons to explain why they prefer to use the redinha instead of the traditional methods, citing for example higher catches, how easy it is to use this method and how fast they can catch a crab with it (Nascimento et al. 2011).

\section{1) Sex ratio and size}

After 1995, the proportion of male crabs was always superior to the proportion of female, unlikely to what was expected, as the female crabs theoretically do not suffer any exploitation pressure, due to a legal prohibition. The carapace width also varied significantly for both males and females, with both sexes showing a reduction in carapace size. For the same reason explained above, the reduction in the female carapace width was something unexpected. Illegal fishing or again, the use of "redinha", could explain such change in sex ratio and the decrease observed in size. The unregulated use of predatory techniques, besides maximizing the fishing pressure, can lead to the prevalence of adult crabs with smaller average size, altering the local population structure of the species (Jankowsky et al. 2006). However, again it is important to consider the gatherers' knowledge in recognizing the crab size and sex that are most financially profitable for them. One should also consider a piece of information given by the gatherers' themselves regarding the presence of outsiders in the area. If these are opportunistic gatherers, they might not have the necessary knowledge to fish sustainably.

The crab gatherers perceived the higher abundance of male in both periods as well as the reduction in the size of individuals in general.

\section{Information reliability}

Broadly, the gatherers provided reliable information in terms of general trends. For example, they reported a reduction in the stock, the prevalence of male crabs and the decrease on the average size of individuals. Furthermore, their information on the months of lower and higher catches was also in accordance with the observed in the landing data and with what is shown on the literature (Nordi 1992; Souto 2004). The fluctuation on the catch over the months seems to be strongly connected to the lifecycle of the crab, and the lifecycle on the other hand is influenced by the tidal cycle (Alves and Nishida 2002). The period of preparation for the moult (carapace change) (May to August) corresponds to the phase in which the crab is fatter and becomes more skittish, harder to catch. Later on this phase (July and August) it is harder to find the crabs, as they close themselves inside their galleries to start the moult. The period from September to October, corresponding to the moult phase, is the time when the crab carapace is still soft, and apparently the consumption of this animal during this stage is avoided, probably due to a food taboo (Alves and Nishida 2002; Souto 2007). After this period, the crabs start losing their carapace, ceasing the phase of low catch. The months of high capture start after the moult, when the crab is "thinner" and needs to leave the gallery more often to feed (Souto 2004). As shown by the $T$ test the difference between the average catch of these two periods is significant, supporting the information provided by the gatherers.

On the other hand, crab gatherers overestimated the information regarding catch and effort. Informants can react to opportunities and threats perceived by them while answering surveys, taking the chance to modify the real values (Jones et al. 
2008). For example, they can try to bias their values down or upwards, to hide an illegal activity or to be better recognized by others (Sheil and Wunder 2002). Two distinct hypotheses could be used to try to explain this pattern of overestimating values. In the case of overestimating their past events, it could be showing the perception that the past was better and more profitable (O'Donnell et al. 2010). The second hypothesis regards a biased perception by the gatherers towards a "community average return". Nowadays, the use of an intensive fishing tool, as the "redinha", eventually results in higher catches. The data suggests, by its outliers, that currently it is more common to have extreme catch events, well above the median. The gatherers could be highlighting these events, which certainly are more remarkable than the median ones. This would be in agreement with what was shown by a study in Madagascar (Jones et al. 2008), in which the best gatherers reduced their information about capture, in order to present values around the average catch of the community.

\section{Conclusion}

The annual catch of $U$. cordatus increased over the 12 years. However, this probably happened in response to a higher catch effort and not necessarily due to an increase in the amount of crab in the mangrove. The new technique for catching crabs, the redinha, could be responsible for such an increase in the effort, and as a consequence, it could be masking the real status of $U$. cordatus stock in the region, by facilitating the catch, increasing the productivity and giving a false impression of abundance. However, this needs to be better investigated, as it is unlikely that experienced gatherers would use redinha in a predatory way, as they are able to identify the sex and the size of the crab before setting this trap.

The majority of gatherers perceived the changes that are happening in the mangrove and in the $U$. cordatus population, such as changes in the sex ratio and in the carapace size, showing a possible efficient use of questionnaires to obtain reliable and cost-effective data for scientific research. However, this method also showed some inaccuracy when gatherers were asked to estimate their catches in the past and in the present, indicating that it should be used with caution, especially when questions demand recollections of long periods of time or when it requires values that can have local interests involved.

\section{Acknowledgments}

We are very thankful to all the crab gatherers, who despite their hard and time consuming activity, found some time to answer our interview. To the Brazilian Institute of Environmental and Renewable Natural Resources (IBAMA), especially A.J. Vasconcelos, for making the long temporal data series available. To F. Freire and C.E.R.D. Alencar for giving suggestions on the text and providing some help with the statistics and to I. Terra for preparing the map.

\section{References}

Alves RRN, Nishida AK (2002) A ecdise do caranguejo-uçá, Ucides cordatus L. (DECAPODA, BRACHYURA) na visão dos caranguejeiros. Interciencia 27:110-117. 
Alves RRN., Nishida AK (2003). Aspectos socioeconômicos e percepção ambiental dos catadores de caranguejo-uçá Ucides cordatus cordatus (L.1763) (Decapoda, Brachyura) do estuário do rio Mamanguape, Nordeste do Brasil. Interciencia, 28: 36-43.

Alves RRN, Nishida AK, Hernandez MIM (2005). Environmental Perception of Gatherers of the Crab Caranguejo-uçá (Ucides cordatus, Decapoda, Brachyura) Affecting Their Collection Attitudes. Journal of Ethnobiology and Ethnomedicine, 1, 1-8.

Amaral ACZ, Jablonski S (2005). Conservação da biodiversidade marinha e costeira no Brasil. Megadiversidade, v. 1, n. 1, p. 43-51.

Anderson SC, Lotze HK; Shackell NL (2008). Evaluating the knowledge base for expanding lowtrophic-level fisheries in Atlantic Canada. Can J Fish Aquat Sci 65: 2553-2571.

Anderson SC, Mills Flemming J, Watson R, Lotze HK (2011). Rapid Global Expansion of Invertebrate Fisheries: Trends, Drivers, and Ecosystem Effects. PLoS ONE, 6(3): e14735.

Andrew NL, Agatsuma Y, Ballesteros E, Bazhin AG, Creaser EP, Barnes DKA, Botsford LW, Bradbury A, Campbell A, Dixon JD (2002) Status and management of world sea urchin fisheries. Oceanography and marine biology 40:343-425.

Barboza, RSL; Neumann-Leitão, S; Barboza, MSL; Batista-Leite, LMA (2008). "Fui no mangue catar lixo, pegar caranguejo, conversar com o urubu": Estudo socioeconômico dos catadores de caranguejo no litoral norte de Pernambuco. Revista Brasileira de Engenharia de Pesca, 3(2), p. 117 - 134.

Boeger WA, Pie MR, Ostrensky A, Patella L (2005) Lethargic crab disease: multidisciplinary evidence supports a mycotic etiology. Memórias do Instituto Oswaldo Cruz 100:161-167.

Botelho ERRO, Santos MCF, Pontes ACP (2000) Algumas considerações sobre o uso da redinha na captura do caranguejo-uçá, Ucides cordatus (Linnaeus, 1763) no litoral sul de Pernambuco - Brasil. Bol. Tec. Cient. CEPENE 8(1):55-71.

De Boer WF, Blijdenstein AF, Longamane F (2002) Prey choice and habitat use of people exploiting intertidal resources. Environmental Conservation 29:238252.

Diele K, Koch V, Saint-Paul U (2005) Population structure, catch composition and CPUE of the artisanally harvested mangrove crab Ucides cordatus (Ocypodidae) in the Caeté estuary, North Brazil: Indications for overfishing? Aquatic Living Resources 18:169-178.

Erman NA (1996). Status of Aquatic Invertebrates. Sierra Nevada Ecosystem Project: Final report to Congress. Assessments and scientific basis for management options 2:987-1007.

Firmo AMS, Tognella MMP, Có WLO, Barboza RRD, Alves RRN (2011) Perceptions of environmental changes and Lethargic crab disease among crab harvesters in a Brazilian coastal community. Journal of Ethnobiology and Ethnomedicine, 7:34.

Fiscarelli AG, Pinheiro MAA (2002) Perfil sócio-econômico e conhecimento etnobiológico do Catador de caranguejo-uçá, ucides cordatus (Linnaeus, 1763), nos Manguezais de iguape ( $24^{\circ} 4^{\prime}$ 's), SP, Brasil. Actualidades Biologicas 24: 39-52. 
Fox J (2005). The R Commander: A Basic Statistics Graphical User Interface to R. Journal of Statistical Software 14: 1-42.

Goes P, Branco JO, Pinheiro MAA, Barbieri E, Costa D, Fernandes LL (2010) Bioecology of the uçá-crab, Ucides cordatus (Linnaeus, 1763), in Vitória Bay, Espírito Santo State, Brazil. Brazilian Journal of Oceanography 58:153163.

Helene AF, Ribeiro PL (2011) Brazilian scientific production, financial support, established investigators and doctoral graduates. Scientometrics, 89, 677-686.

IBAMA (2011). Proposta de plano nacional de gestão para o uso sustentável do Caranguejo-Uçá, do Guaiamum e do Siri-Azul.

Jankowsky M, Pires JSR, Nordi N (2006). Contribuição ao manejo participativo do caranguejo-uçá, Ucides cordatus (L., 1763), em Cananéia - SP. Boletim do Instituto de Pesca 32:221-228.

Jones JPG, Andriamarovololona MM, Hockley N, Gibbons JM, Milner-Gulland EJ (2008) Testing the use of interviews as a tool for monitoring trends in the harvesting of wild species. Journal of Applied Ecology 45:1205-1212.

Kristensen $E$ (2008) Mangrove crabs as ecosystem engineers; with emphasis on sediment processes. Journal of Sea Research 59:30-43.

Lunn KE, Dearden P (2006) Monitoring small-scale marine fisheries: An example from Thailand's Ko Chang archipelago. Fisheries Research 77:60-71.

Magalhães A, da Costa RM, da Silva R, Pereira LCC (2007) The role of women in the mangrove crab (Ucides cordatus, Ocypodidae) production process in North Brazil (Amazon region, Pará). Ecological Economics 61:559-565

Melo GAS (1996). Manual de identificação dos Brachyura (caranguejos e siris) do litoral brasileiro. São Paulo: Plêiade/FAPESP, 497p.

MMA - Ministério do Meio Ambiente (2004). Instrução normativa $n^{\circ} 5$, de 21 de maio de 2004.

Moura RL, Minte-Vera CV, Curado IB, Francini-Filho RB, Rodrigues HDCL, Dutra GF, Alves DC, Souto FJB (2009) Challenges and prospects of fisheries comanagement under a marine extractive reserve framework in Northeastern Brazil. Coastal Management 37:617-632

Nascimento DM, Mourão JS, Alves RRN (2011) A substituição das técnicas tradicionais de captura do caranguejo-uçá (Ucides cordatus) pela técnica "redinha" no estuário do rio mamanguape, Paraíba. Sitientibus série Ciências Biológicas 11: 113-119.

Nascimento SA (1993) Biologia do caranguejo-uçá Ucides cordatus. ADEMA Administração Estadual do Meio Ambiente, 45p., Aracajú, SE, Brasil.

Nishida AK, Nordi N, Alves RRN (2006) The lunar-tide cycle viewed by crustacean and mollusc gatherers in the State of Paraíba, Northeast Brazil and their influence in collection attitudes. Journal of Ethnobiology and Ethnomedicine 2:1-12.

Nordi, N (1992). Os catadores de caranguejo-uçá (Ucides cordatus) da região de Várzea Nova (PB):uma abordagem ecológica e social. São Carlos. 107p. (Tese de Doutoramento. Universidade Federal de São Carlos, SP, Brasil.)

Nordi N (1994) A produção dos catadores do caranguejo-uçá (Ucides cordatus) da região de Várzea Nova, Paraíba. Revista Nordestina de Biologia 9:71-77.

Nordi N, Nishida AK, Alves RRN (2009) Effectiveness of Two Gathering Techniques for Ucides cordatus in Northeast Brazil: Implications for the Sustainability of Mangrove Ecosystems. Human Ecology 37:121-127. 
O'donnell KP, Pajaro MG, Vincent ACJ (2010). How does the accuracy of fisher knowledge affect seahorse conservation status? Animal Conservation. Animal Conservation 13: 526-533. doi:10.1111/j.1469-1795.2010.00377.x

Paiva MP (1997). Recursos pesqueiros estuarinos e marinhos do Brasil. Edições UFC, 286 p., Fortaleza.

Perry RI, Walters CJ, Boutillier JA (1999) A framework for providing scientific advice for the management of new and developing invertebrate fisheries. Reviews in Fish Biology and Fisheries 9:125-150.

Pinheiro MAA, Fiscarelli AG (2001). Manual de apoio à fiscalização do caranguejo-uçá (Ucides cordatus). Instituto Brasileiro do Meio Ambiente (IBAMA)/Centro de Pesquisa e Extensão Pesqueira das Regiões Sudeste e Sul (CEPSUL), 1 ed., Itajaí, 60 p.

R DEVELOPMENT CORE TEAM (2012). R: A language and environment for statistical computing. R Foundation for Statistical Computing, Vienna, Austria. ISBN 3-900051-07-0, URL http://www.R-project.org/.

Ronnback $P$ (1999). The ecological basis for economic value of seafood production supported by mangrove ecosystems. Ecological Economics, 29, 235-252.

Schmidt AJ, Oliveira MA, May M, Souza EP, Araujo SMB, Tararam AS (2005). Ocorrência de mortalidade em massa do caranguejo-uçá Ucides cordatus cordatus em manguezal de Caravelas/BA. In: Anais do Congresso Brasileiro de Oceanografia, 2. Vitória, ES.

Schories D, Barletta-Bergan A, Barleta M, Krumme U, Mehlig U, Rademaker V (2003) The keystone role of leaf-removing crabs in mangrove forests of North Brazil. Wetlands Ecol. Managem. 11:243-255.

Sheil D, Wunder S (2002) The value of tropical forest to local communities: complications, caveats, and cautions. Conservation Ecology 6:9.

Sirén A, Hambäck P, Machoa J (2004) Including spatial heterogeneity and animal dispersal when evaluating hunting: a model analysis and an empirical assessment in an Amazonian community. Conservation Biology 18:13151329

Souto, FJB (2007). Uma abordagem etnoecológica da pesca do caranguejo, Ucides cordatus, Linnaeus, 1763 (Decapoda: Brachyura), no manguezal do Distrito de Acupe (Santo Amaro-BA). Biotemas 20: 69-80

Souto, FJB (2004). Da Lama Ao Caos: A Ciência Que Veio Do Mangue. São Carlos. 505p. (Tese de Doutoramento. Universidade Federal de São Carlos).

Souza FES (2004). Evolução Morfodinâmica da Região de Influência Estuarina do Rio Curimataú - RN, Com Ênfase nas Alterações do Ambiente Deposicional de Manguezal e a Integração de Geodados em SIG. Tese (Doutorado em Geodinâmica e Geofísica) - UFRN, Centro de Ciências Exatas e da Terra, Natal - RN.

Thomas F (2007) The Behavioral Ecology of Shellfish Gathering in Western Kiribati, Micronesia. 2: Patch Choice, Patch Sampling, and Risk. Human Ecology 35:515-526.

Vasconcellos SEM, Vasconcelos JA, Ivo CTC (1999) Estudo sobre a biologia do caranguejo-uçá, Ucides cordatus cordatus, (Linnaeus, 1763), capturado no estuário do Rio Curimatau (Canguaretama - Rio Grande do Norte). Boletim Tecnico Cientifico Cepene 7:1-46 
Capistrano and Lopes 2012. Crab gatherers perceive concrete changes in the life history traits of Ucides cordatus (Linnaeus, 1763), but overestimate their past and current catches. Ethnobio Conserv 1:7

White, PCL; Jennings, NV; Renwick, AR; Barker, NHL (2005). Questionnaires in ecology: a review of past use and recommendations for best practice. Journal of Applied Ecology 42:421-430. 